\title{
STABILITY OF TEMPERATE ICE GAPS AND ICE SHEETS RESTING ON BEDS OF DEFORMABLE SEDIMENT
}

\author{
By G. S. Boulton \\ (School of Environmental Sciences, University of East Anglia, Norwich NR4 7 TJ, England) \\ and A. S. Jones \\ (Department of Mathematics, University of Queensland, Brisbane, Queensland 4067, \\ Australia)
}

\begin{abstract}
Although theories of glacier movement generally assume that glaciers flow over rigid rock beds, there are many places where glaciers rest on beds of deformable sediment, and the great Pleistocene ice sheets which extended from time to time over much of Northern Europe and North America were largely underlain by such beds. Observations show that a large proportion of the forward movement of a glacier lying on such a bed may be contributed by deformation of the bed rather than the glacier. A theory is developed in which the glacier surface profile is related to the hydraulic and strength properties of potentially deformable bed materials. If these have a high hydraulic transmissibility, melt water is readily discharged subglacially, the bed is stable, and the profile is a normal parabolic one, governed by the rheological properties of ice. If bed transmissibility is low, water pressures build up, the bed begins to deform, and a lower equilibrium profile will develop, so that in an extreme case the glacier approximates to a thin flat sheet, similar to an ice shelf. It is suggested that such behaviour may have occurred at the margins of large Pleistocene ice sheets over North America and Europe, and evidence in support of this is drawn from the reconstructed shapes of these ice margins, anomalously small amounts of isostatic rebound, anomalously high retreat-rates, and the presence of glaciotectonic structures. Reasons are suggested to explain why this behaviour should have been important for Pleistocene glaciers which penetrated into currently temperate latitudes but does not appear to be important in large modern glaciers.
\end{abstract}

RÉSUmÉ. Stabilité de calottes de glace tempérée reposant sur des lits de sédiments déformables. Bien que les théories sur le mouvement des glaciers supposent en général que les glaciers s'écoulent sur des lits rocheux rigides, il arrive souvent que les glaciers reposent en fait sur des sédiments déformables et la grande calotte glaciaire pleistocène qui s'est parfois étendue sur la plus grande partie de l'Europe du Nord et de l'Amérique du Nord était en grande partie supportée par de tels lits. Des observations montrent qu'une forte proportion des avancées de glaciers reposant sur un tel lit peut être le résultat de la déformation du lit plus que de glacier. On a développé une théorie selon laquelle le profil de la surface du glacier est mis en relation avec les propriétés hydrauliques et plastiques des matériaux d'un lit déformable. S'ils ont une forte perméabilité, l'eau de fonte est rapidement transmise sous le glacier, le lit est stable et le profil est normalement parabolique, conformément aux lois rhéologiques de la glace. Si la perméabilité à l'eau est faible, la pression hydrostatique croît, le lit commence à se déformer et un profil d'équilibre plus bas en altitude se développe de sorte que, en des cas extrêmes, le glacier ressemble à une feuille mince plate, semblable à la banquise. On suggère qu'un tel comportement peut avoir pris place sur les franges de la grande calotte pleistocène sur l'Amérique du Nord et l'Europe, et on y voit des preuves dans la reconstitution des formes de ces franges glaciaires avec des remontées isostatiques anormalement faibles, des vitesses de retrait anormalement élevées et la présence de structures glacitectoniques. On suggère des raisons qui expiiquent pourquoi ce comportement a dû être important pour les glaciers Pleistocènes qui pénétraient des latitudes ordinairement tempérées mais ne semble pas jouer un grand rôle dans les grands glaciers actuels.

Zusammenfassung. Die Stabilität temperierter Eiskappen auf deformierbarem sedimentärem Untergrund. Obwohl die Theorien der Gletscherbewegung im allgemeinen davon ausgehen, dass Gletscher in Betten aus festem Fels fliessen, gibt es viele Stellen, wo Gletscher auf deformierbaren Sedimenten liegen; dies gilt weitgehend von den grossen pleistozänen Eisschilden, die sich mehrfach über weite Gebiete von Nordeuropa und Nordamerika ausbreiteten. Beobachtungen zeigen, dass ein Grossteil der Vorwärtsbewegung solcher Gletscher eher von der Deformation des Untergrundes als von der des Gletschers herrühren kann. Eine Theorie wird entwickelt, die das Profil der Gletscheroberfläche zu den hydraulischen und Festigkeitseigenschaften potentiell deformierbaren Untergrundmaterials in Beziehung setzt. Wenn dieses eine hohe hydraulische Durchlässigkeit besitzt, wird Schmelzwasser reichlich subglazial abgeführt; das Bett ist dann stabil und das Profil normal parabolisch, entsprechend den rheologischen Eigenschaften des Eises. Ist die Durchlässigkeit hingegen gering, so steigt der Wasserdruck, das Bett beginnt, sich zu verformen, und es entwickelt sich ein tieferes Gleichgewichtsprofil; im Extremfall nähert sich der Gletscher einer dünnen, flachen Decke, ähnlich einem Schelfeis. Es wird angenommen, dass solches Verhalten an den Rändern der grossen pleistozänen Eisschilde über Nordamerika und -europa eingetreten ist; diese Annahme lässt sich stützen durch die rekonstruierte Gestalt dieser Eisränder, durch die ungewöhnlich niedrigen Werte des isostatischen Wiederaufstiegs, durch ungewöhnlich hohe Rückzugsraten und durch das Vorhandensein glazitektonischer Strukturen. Begründungen werden angegeben, um zu erklären, weshalb dieses Verhalten bedeutungsvoll für pleistozäne Gletscher, die in heute gemässigte Breiten vordrangen, gewesen sein soll, jedoch keine Bedeutung für grosse, derzeit bestehende Gletscher zu haben scheint. 
Theories developed to account for the surface profiles of ice caps and ice sheets assume that the ice rests on a rigid surface and that the profile depends primarily on both the rheological properties of the ice (Nye, 1957) and the thickness of a lubricating water film between the glacier and its bed (Nye, 1957; Weertman, 196I). Whereas the assumption of a rigid bed is probably correct for most modern glaciers, there are also many which are partly underlain by unlithified sediments which are potentially deformable, and we know that large proportions of the beds of the great ice sheets which covered much of north-west Europe and North America from time to time during the Quaternary contained comprised deformable sediment.

\section{SEDIMENT DEFORMATION BENEATH GLAGIERS}

Where the recession of temperate glaciers reveals a surface of subglacially-deposited till or other unlithified sediment, it is not, as has been commonly supposed (Kazi and Knill, r969), hard and overconsolidated, but extremely soft and with a high water content (Baranowski, 1975; Boulton and Paul, 1976). This is not merely a feature of the glacier margin but has been found to occur subglacially some distance from the glacier front. This soft horizon has a very low shear strength (Boulton and others, 1974) but often overlies a denser till horizon. The pattern of strain in the till bed underlying Breiðamerkurjökull in Iceland, established from the movement of markers inserted by drilling from an englacial tunnel, is shown in Figure I. A large proportion of the total forward movement of the glacier is accounted for by deformation of the glacier bed rather than by slip at the glacier-bed interface. Measurements indicate that $88 \%$ of the basal movement is taken up by such deformation compared to $12 \%$ by slip at the glacier-bed interface. (Details of these measurements will be presented in a

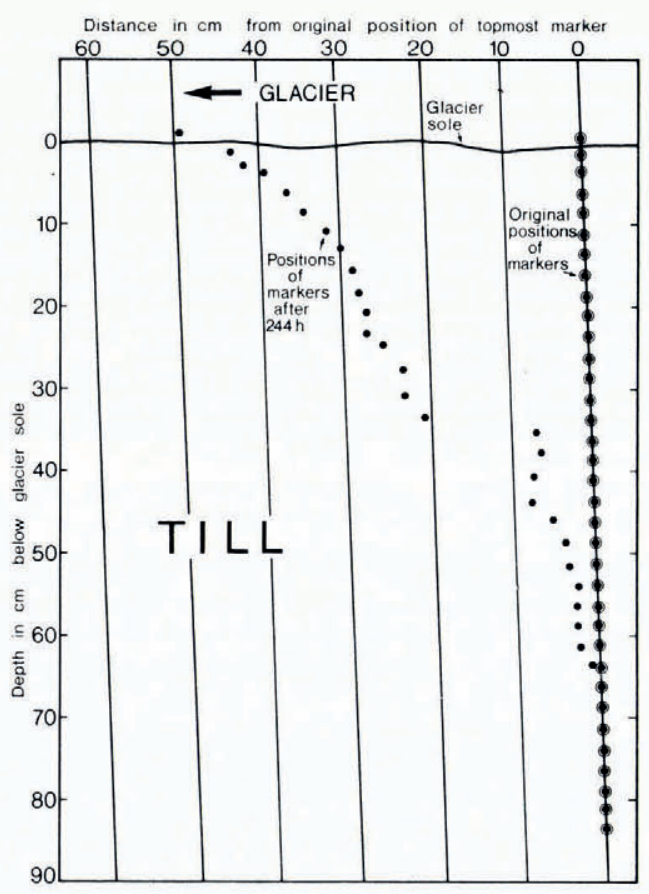

Fig. I. Displacement of a series of markers inserted in till beneath Breiðamerkurjökull in Iceland. The markers were drilled in from an englacial tunnel and dug out after $244 \mathrm{~h} .88 \%$ of the forward movement of the glacier at this point occurs through deformation of the substratum. 
forthcoming paper.) The reason for the limited slip at the ice-bed interface is the relatively high roughness of a sediment interface, in the critical roughness range, compared with glacially eroded bedrock surfaces (Boulton, [ $\left.{ }^{\mathrm{c}} \mathrm{I} 975\right]$ ).

The presence of extensive areas of subglacially deformed sediment in regions occupied by Quaternary ice sheets in Europe and North America indicates that the beds of these ice sheets were unstable in parts (e.g. Slater, I926; Kupsch, I962; Woldstedt, I965; Lavrushin, I971). For instance, extensive areas of Denmark, Germany, and Poland occupied by the periphery of the north-west European late-Weichselian ice sheet show extensive development of tectonic structures in what are presumed to have been subglacial sediments. It is thus useful to investigate the possible influence of a deforming substratum on the dynamic behaviour of glaciers.

\section{THE DEFORMING-BED MODEL}

Let us consider an ice cap or ice sheet, with its sole at the pressure-melting point, resting on a uniformly-thick stratum of permeable unlithified sediment which itself overlies a rigid impermeable substratum. Melt water produced basally is able to drain through the sediments. If drainage through the sediments is slow, pore-water pressure $p$ will tend to build up so as to decrease the effective pressure $\rho_{\mathrm{i}} g H-p$ in the sediments, and thus to decrease their shear strength $S$. For a cohesive sediment (e.g. till or clay),

$$
S=C+\left(\rho_{\mathrm{i}} g H-p\right) \tan \phi,
$$

where $C$ is the cohesion, $\phi$ the angle of internal friction, $\rho_{\mathrm{i}}$ the density of ice, $H$ the ice thickness, and $g$ the acceleration due to gravity, whereas for a non-cohesive sediment,

$$
S=\left(\rho_{\mathrm{i}} g H-p\right) \tan \phi .
$$

We shall assume that if $S>\mathrm{I}$ bar then the glacier bed will remain rigid and glacier movement will be largely controlled by the flow of ice, but if $S<\mathrm{I}$ bar then we shall assume glacier movement to be controlled by deformation of the sediment bed.

If we assume that the thickness $H$ of the glacier is known, and if the accumulation-rate is $A F\left(x / x_{\mathrm{f}}\right.$ ) (where $x_{\mathrm{f}}$ is the distance from source to snout in a two-dimensional ice cap, and $F$ has a maximum value of $\mathrm{I}$ ) then the horizontal velocity of the glacier at any point (assumed constant through a vertical column) is given by

$$
U=\left(\frac{A}{H}\right) \int_{0}^{x} F \mathrm{~d} s=\left(\frac{A}{H}\right) G(x) .
$$

The basal shear stress is given by $-\rho_{\mathrm{i}} g H \mathrm{~d} H / \mathrm{d} x$, and hence the basal temperature gradient is (Jones, I978)

$$
\frac{\mathrm{d} T}{\mathrm{~d} z}=-\gamma_{g}-\frac{\tau_{\mathrm{b}} U}{k}=-\gamma_{g}+\frac{\rho_{\mathrm{i}} g}{k} \frac{\mathrm{d} H}{\mathrm{~d} x} G(x) A,
$$

where $\gamma_{g}$ is the geothermal heat flux, $\tau_{\mathrm{b}}$ the basal shear stress, and $k$ the thermal conductivity of ice. If a constant proportion $c$ (usually taken as 0.5) of the heat input is used for melting the ice, then the melting-rate is given by

$$
M=-\frac{c k}{L \rho_{i}} \frac{\mathrm{d} T}{\mathrm{~d} z},
$$

where $L$ is the latent heat of fusion of ice. If the deformable bed has a thickness $t$, then for a steady-state condition the horizontal velocity of the melt water is given by

$$
V=\frac{\mathrm{I}}{t} \int_{0}^{x} M(s) \mathrm{d} s,
$$


and from Darcy's law

$$
\frac{\mathrm{d} p}{\mathrm{~d} x}=-\frac{\rho_{\mathrm{w}} g}{K} V
$$

where $p$ is the water pressure, $\rho_{\mathrm{w}}$ the density of water, and $K$ the permeability of the sediments.

We initially consider the case of two subglacial materials, a gravel, which is relatively incompressible and in which permeability is not strongly dependent on effective pressure, and a till, in which permeability is strongly dependent upon effective pressure. We shall use for the till a relationship determined experimentally for a till from Breiðamerkurjökull in Iceland:

$$
\kappa=K_{\mathrm{o}} \exp \left\{m\left(\rho_{\mathrm{i}} g h-p\right)\right\}
$$

in the region I bar $\leqslant\left(\rho_{\mathrm{i}} g h-p\right) \leqslant$ Io bar, where $K_{0}=\mathrm{I} .6 \times 1 \mathrm{IO}^{-6} \mathrm{~m} \mathrm{~s}^{-1}$ and $m=-5.6 \times \mathrm{IO}^{-\mathrm{I}}$ bar $^{-1}$.

From Equation (5) we can calculate $p$ which is for the gravel

$$
p=\frac{\rho_{\mathrm{w}} g}{K} \int_{x}^{x_{\mathrm{t}}} V \mathrm{~d} x
$$

and for the till

$$
\text { - } \quad p=-\frac{\mathrm{I}}{m} \log \left(\mathrm{I}+\frac{m \rho_{\mathrm{w}} g}{K_{0}} \int_{x}^{x_{\mathrm{t}}} V \exp \left(-m \rho_{\mathrm{i}} g h\right) \mathrm{d} x\right) .
$$

The basal shear stress is now recalculated in terms of the effective pressure:

$$
-\rho_{\mathrm{i}} g H \frac{\mathrm{d} H}{\mathrm{~d} x}=\tan \phi\left(\rho_{\mathrm{i}} g H-p\right),
$$

where $\phi$, the angle of internal friction of the sediment, is a constant non-dimensional measure of the ratio of effective pressure to shear strength. Hence, integrating, we obtain

$$
H^{2}=2 \tan \phi \int_{x}^{x_{\mathrm{t}}}\left(H-\frac{\rho}{\rho_{\mathrm{i}} g}\right) \mathrm{d} x,
$$

subject to the restrictions that $\mathrm{o} \leqslant \tau_{\mathrm{b}} \leqslant \mathrm{I}$ bar and $H>\mathrm{o}$ for $x<x_{\mathrm{f}}$. This gives us new values for $H$ which can be used in place of the previous estimate. The calculations are then repeated iteratively. For till with a residual strength $C$, Equation (9) becomes

$$
-\rho_{\mathrm{i}} g H \frac{\mathrm{d} H}{\mathrm{~d} x}=C+\tan \phi\left(\rho_{\mathrm{i}} g H-p\right),
$$

and Equation (10) becomes

$$
H^{2}=2 \int_{x}^{x_{\mathrm{f}}}\left\{\frac{C}{\rho_{\mathrm{i}} g}+\tan \phi\left(H-\frac{p}{\rho_{\mathrm{i}} g}\right)\right\} \mathrm{d} x,
$$

subject to $C \leqslant \tau_{\mathrm{b}} \leqslant \mathrm{I}$ bar.

The EFFECT OF A DEFORMING Bed on theORETICAL PROFILES OF ICE CAPS AND ICE SHEETS

The response of the deforming-bed model to different conditions of bed geology, mass balance, and glacier size was determined. The assumed pattern of accumulation, scaled to give a maximum net accumulation-rate of $\mathrm{I}$, is shown in Figure 2. For simplicity, the pattern of accumulation which was specified varied with horizontal distance rather than with elevation 
(this would have been more realistic). For most of the calculation a maximum accumulationrate of $2 \mathrm{~m}_{\text {year-1 }}$ was used, corresponding to an average accumulation-rate of $1.125 \mathrm{~m}_{\text {year }}^{-1}$ above the equilibrium line.

Several models of bed geology were used: one consisting entirely of gravel, one consisting entirely of till, and two consisting of alternations of till and gravel, but in different sequence, and two sizes of glacier, one with $x_{\mathrm{f}}=40 \mathrm{~km}$ and one with $x_{\mathrm{f}}=240 \mathrm{~km}$.

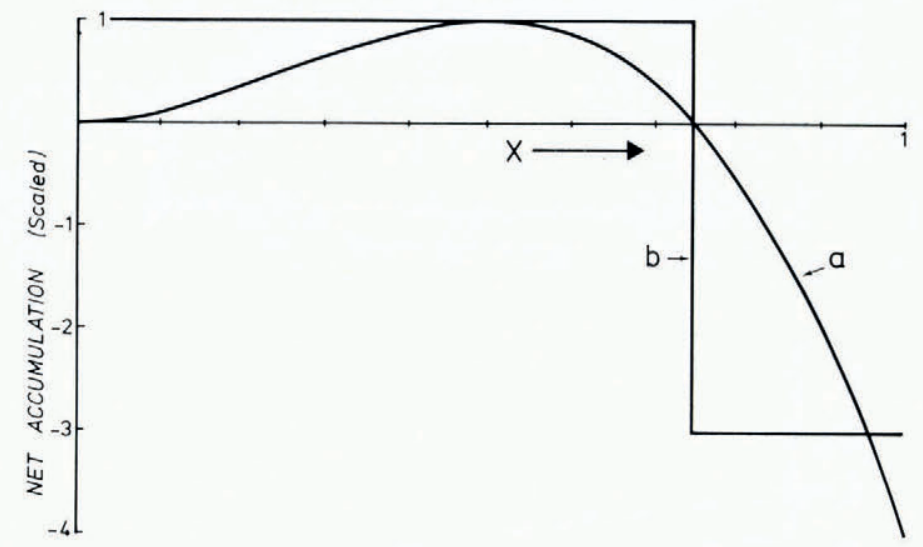

Fig. 2. Patterns of net accumulation (curves $a$ and $b$ ) used in constructing glacier profiles.

\section{The gravel-bed condition}

For the gravel bed we assume $K=\mathrm{IO}^{-2}$ and $0.5 \leqslant \tan \phi \leqslant \mathrm{I}$. For maximum net accumulation-rates of $2 \mathrm{~m}^{-1}$ year $^{-1}$, the profiles for $x_{\mathrm{f}}=40 \mathrm{~km}$ and $x_{\mathrm{f}}=240 \mathrm{~km}$ are normal parabolic ones, indicating that the shear strength of the gravel is higher than that of ice in these cases. However, if the accumulation-rates are raised, thus increasing the velocity of the glacier and hence the amount of melt water being produced at the bottom, the shear strength of the gravel is reduced, the glacier begins to slump near to the equilibrium line, and the profile becomes progressively lower as the accumulation-rate increases.

For $x_{\mathrm{f}}=40 \mathrm{~km}$ (Fig. 3a), this slumping first became apparent for a maximum accumulation-rate of about $330 \mathrm{~m}$ year ${ }^{-1}$, whereas for $x_{\mathrm{f}}=240 \mathrm{~km}$ (Fig. $3 \mathrm{~b}$ ) it began when the accumulation-rate was about 8 mear $^{-1}$. This case was also considered with $x_{\mathrm{f}}=1000 \mathrm{~km}$, which needed a maximum accumulation-rate of only $0.25 \mathrm{~m}$ year ${ }^{-1}$ to initiate a slump in the profile.

If a stepped accumulation pattern such as curve b in Figure 2 is used instead of curve a, though with the same average net accumulation-rate, the high parabolic profile is less stable since the average velocity, and hence the rate of production of melt water, is higher in this case (Fig. 3c).

\section{The till-bed condition (or any similarly fine-grained sediment)}

For the till bed we assume $K_{\mathrm{t}}=K_{0} \exp \left\{m\left(\rho_{\mathrm{i}} g h-p\right)\right\}$ and $0.17 \leqslant \tan \phi \leqslant 0.5$. In all cases considered the profile was reduced below the expected parabola for $\tau_{\mathrm{b}}>\mathrm{I}$ (Fig. 4). Where a residual strength $C>0$ was assumed, the profile has a parabolic shape corresponding to $\tau_{\mathrm{b}}=C$, while for $C=\mathrm{o}$ we obtain a flat surface profile, except in the snout region. In this case the glacier approximates to the condition of a floating ice shelf which floats on a deforming sediment bed. 

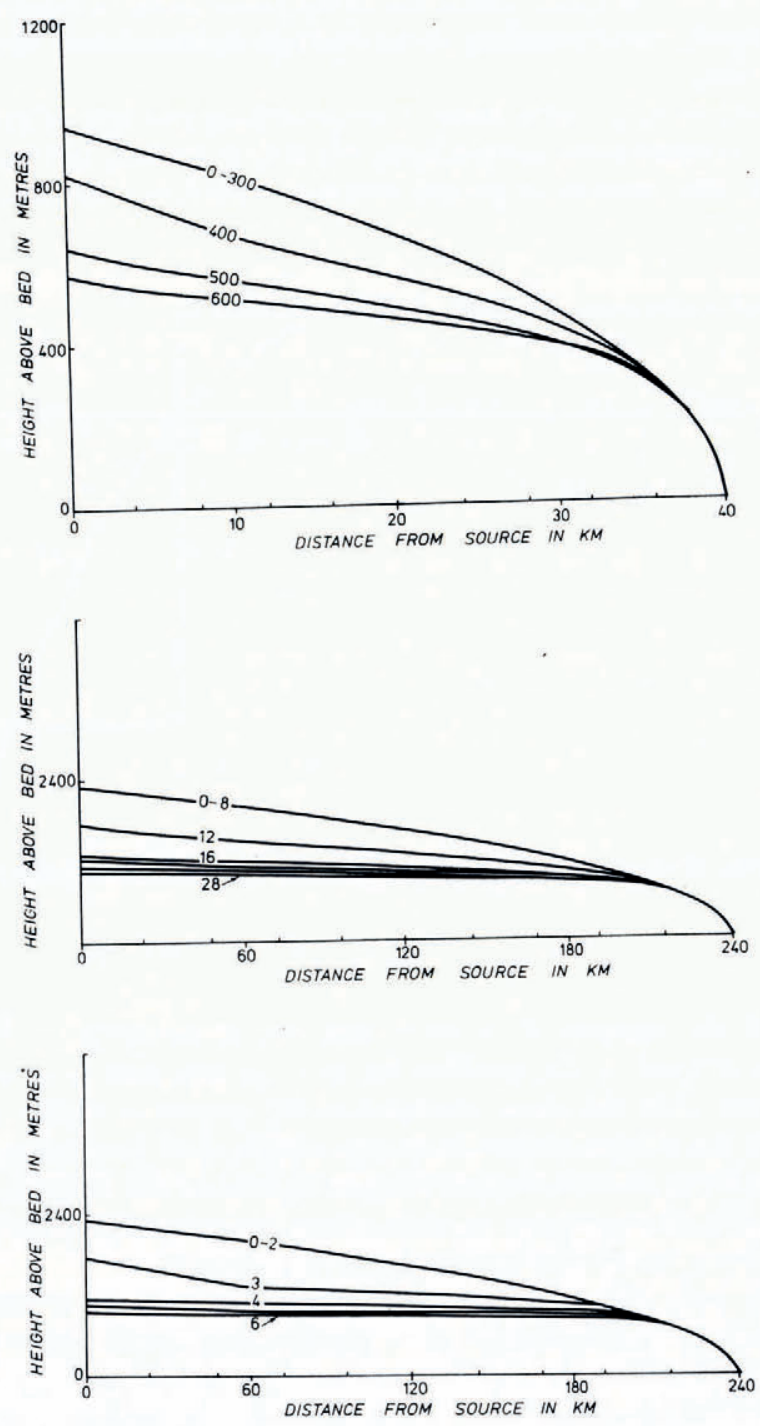

Fig. 3. The influence of pattern and rate of net accumulation on ice-cap profiles. a (upper) A gravel-bed glacier assuming an accumulation pattern similar to that in Figure 2, curve a, and various maximum net accumulation-rates. $x_{p}=40 \mathrm{~km}$. $b$ (centre) As $3 a$, but for an ice cap of $x_{\mathrm{P}}=240 \mathrm{~km} . c$ (lower) As for Figure $3^{b}$ but using a stepped accumulation pattern as shown in Figure 2, curve b.

Beds of more complex geology, e.g. alternating sequences of till and gravel

Here we investigate two types of bed: the first, a source-to-snout sequence of till/gravel/ till/gravel, and the second a sequence of gravel/till/gravel/till. Each bed type has a longitudinal extent of $0.25 x_{\mathrm{f}}$, and the hydraulic and strength properties of each material are as before (Fig. 5).

If the snout rests on gravel, the initial profile is identical to that of a bed consisting entirely of gravel, but when the till bed is reached the angle becomes smaller, the slope depending on the residual strength of the till and becoming zero if $C=0$. The till effectively acts as a dam 


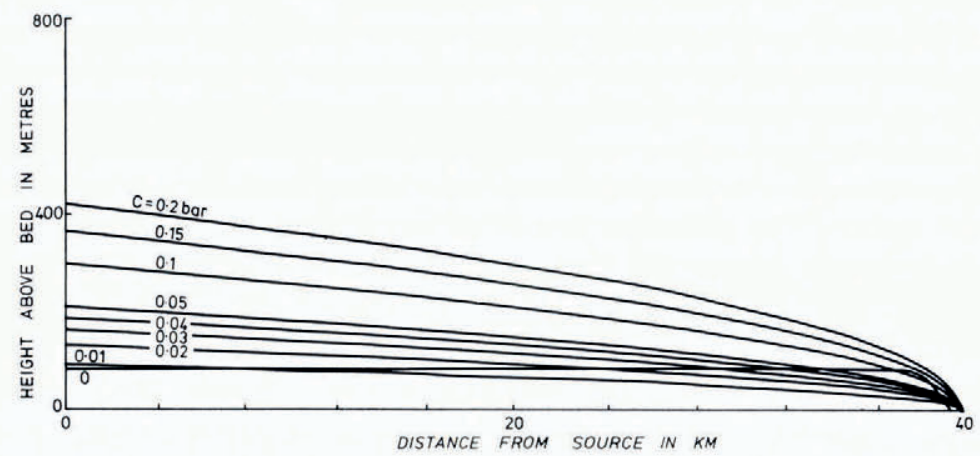

Fig. 4. The influence of till beds of different cohesion $C$ on the profile of an ice cap. Accumulation pattern as in Figure 2, curve $b$. The profile for $C=o$ is anomalous. As the residual shear tends to zero, the ice cap would like to disappear, however, the program insists on an ice cap and hence the solution provides a zone of high shear at the snout holding back a flat section.
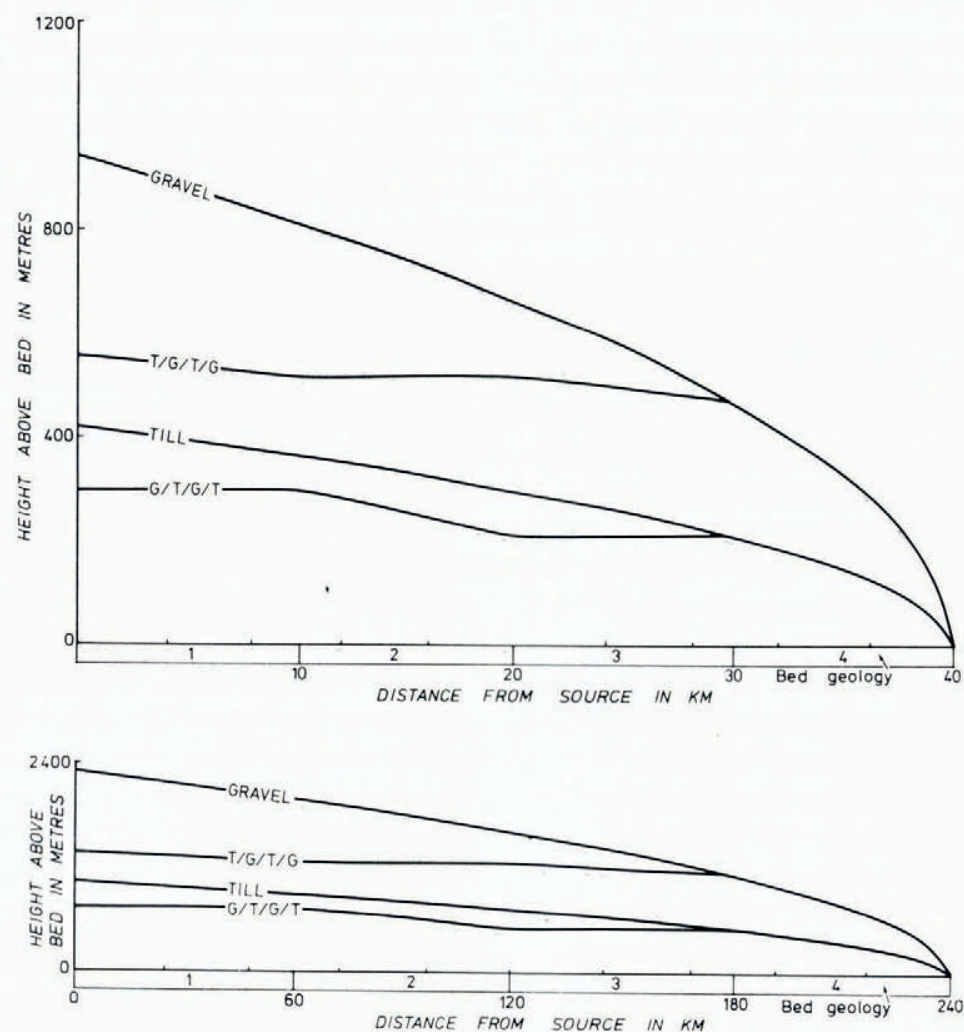

Fig. 5. Abrupt changes in surface slope which may develop with a deforming bed of complex geology for ice caps of a (upper) $x_{\mathrm{f}}=40 \mathrm{~km}$ and $b$ (lower) $x_{\mathrm{f}}=240 \mathrm{~km}$. The blocks $\mathrm{I}, 2,3,4$ below the horizontal axis represent different geological elements. In one case $I$ and $3=$ gravel, 2 and $4=$ till, and in the other $I$ and $3=$ till, 2 and $4=$ gravel. In the first case, the till bed (4) beneath the snout dams subglacial water flow so that the profile is flat up-glacier of this point, except where it is underlain by a bed where $C>0$. In the second case, the damming effect only operates up-glacier of bed 3 (till). For the till, $C=0.2$ bar. 
to water flow and causes a build-up of pore water pressure in the up-glacier gravel bed, causing the ice to "float" and reducing the slope to zero. If $C>0$, the profile then rises again over the till bed as a result of the residual strength, producing a staircase profile. If the snout rests on till, we again have an initial profile which corresponds to a bed entirely on till with the slope beoming zero over the gravel beds.

Further "staircasing" of the profiles may, in practice, occur because of localized water losses into the substrata, which will increase the effective strength of the bed and hence the slope of the profile, and also because of regions of undeformable bed material.

\section{ApPlication OF THE DEFORMING-BED MODEL TO PAST AND PRESENT GLAGIERS}

We do not suggest that our simple model is necessarily a precise description of the glacier surface profiles which might result when the sediment bed of a glacier becomes unstable and deforms continuously. In order to assess its applicability we must examine the evidence that glaciers do behave, or have at some time behaved, in this fashion.

In its simplest form, the theory presented here predicts that the geology of the subglacial bed will influence the surface profile of a glacier, and that ice caps or ice sheets flowing over fine-grained, unlithified sediments (i.e. relatively impermeable with low or zero cohesion) will tend to have a relatively low profile. Unfortunately, we rarely know details of both the subglacial geology and the glacier surface profile. In the case of modern glaciers we know the surface profile, but not the details of bed geology (other than very locally in bore-holes or near the terminus where external geology can be extrapolated beneath the glacier). In the case of ancient glaciers, the geology of the former subglacial bed is often well known, but the surface profile of the vanished ice is difficult to reconstruct.

\section{The shape of Pleistocene ice lobes}

The extent of many former glaciers has been reconstructed from stratigraphic evidence and from moraine patterns. The shape of the margins of some of these glaciers is difficult to explain using typical modern glaciers as models. For example, it is believed by geologists that the ice sheet which reached its maximum extent down the east coast of England during Late Devensian times thrust out a well-defined lobe lying between the English coast and the longitude of the Dogger Bank (Fig. 6a). Reconstructions of the retreat of the Late Weichselian Scandinavian ice sheet from the Baltic region at a slightly later date also show an elongate lobe often referred to as the Baltic Ice Stream (Fig. 6b), and similar lobes are an important feature of the southern margin of the Late Wisconsin Laurentide ice sheet whilst this was near to its maximum extent, and also during its retreat in the region of Hudsons Bay (Fig. 6c).

It is possible, of course, that these lobes may have been radially-flowing domes which were relatively independent centres of ice accumulation near to the edge of a major ice sheet rather than lobes with longitudinal axial flow. However, geological evidence for the direction of flow appears to rule this out. If we look at modern models for lobed glaciers we can identify four ways in which this form is produced:

(a) Valley glaciers draining an ice cap or ice sheet, in which flow is channelled and prevented from spreading laterally.

(b) Piedmont lobes where a large ice discharge flows through a constriction onto a plain. The piedmont lobe spreads radially to take up a semi-circular plan.

(c) Surge lobes, where a reduced basal shear stress produces a low-angle profile. This may be channelled by valley walls, which of course need not be so high as in the case of a normal valley glacier, or it may flow out onto a plain, either through a constriction, or by collapse of part of an ice-cap margin (e.g. Bråsvellbre in Spitsbergen, Barnes 
Ice Cap in Baffin Island, Løken, I969; Holdsworth, I977), in both cases the lobe will tend to spread radially and produce a semi-circular plan.

(d) Floating ice tongues (e.g. Erebus tongue in the Antarctic).

From this we conclude that we are unable to explain by conventional models the elongate lobes which are not confined by well-defined valleys on land. We suggest, however, that they can be explained by a model in which the glacier flows preferentially along a substratum composed of deformable and permeable beds. High subglacial pore water pressures in this substratum cause it to deform and the glacier reaches an equilibrium at a relatively low basal shear stress and with a low surface profile. If the glacier flows beyond this stratum on to relatively undeformable bedrock, basal shear stresses increase and the glacier becomes relatively sluggish with a steep surface profile. Thus, the form of the glacier is substratum controlled. This may account for some of the anomalous lobate ice margins noted above.
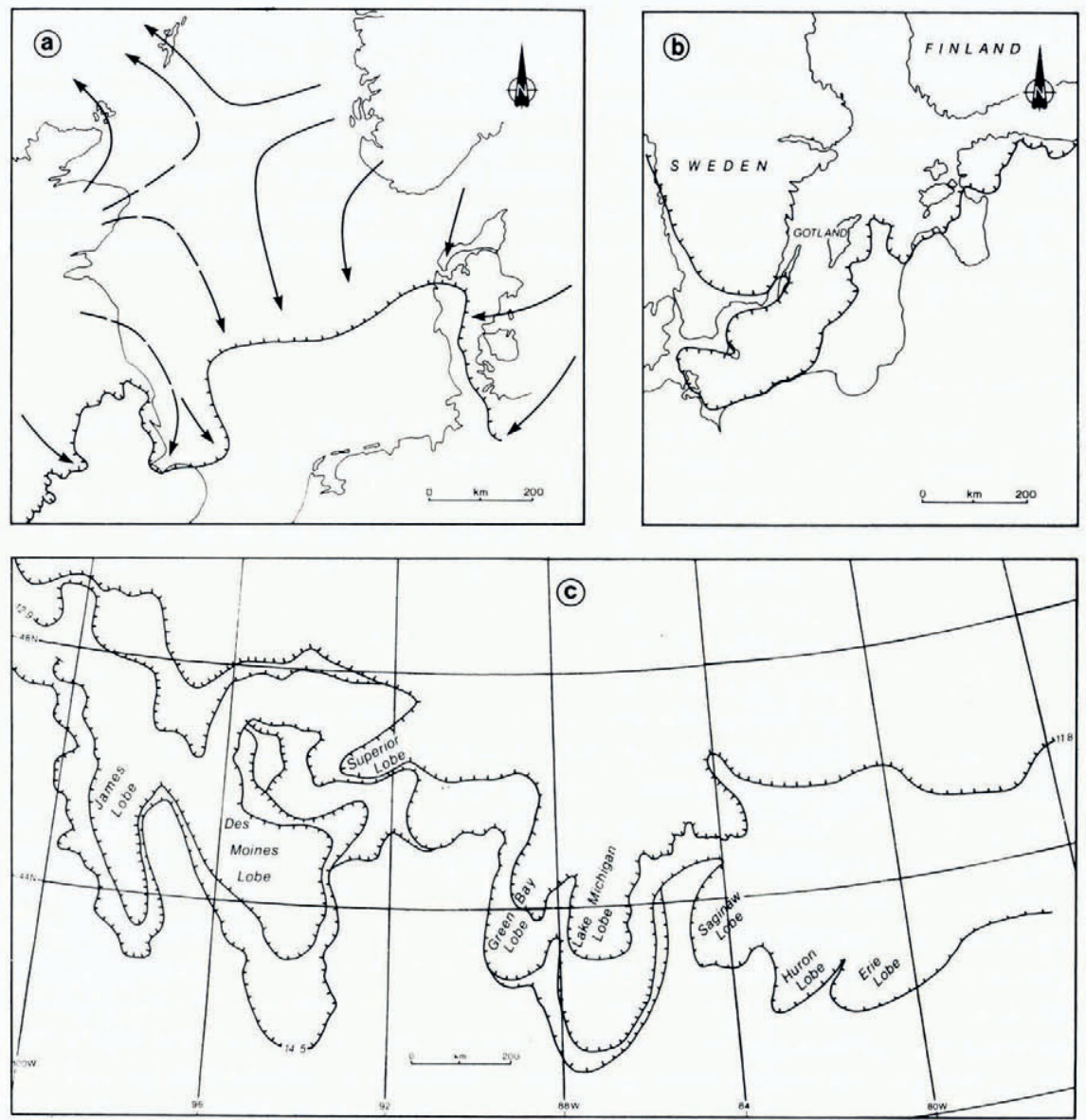

Fig. 6 .

a. Reconstruction of the greatest extent of the Late Devensian (Weichselian) ice sheet in the North Sea Basin showing the ice lobe which is thought to have flowed down the east coast of England.

b. Reconstruction of the Late Weichselian Baltic glacier lobe during its retreat at about 12 ooo years B.P. according to Morner and others (1975).

c. Reconstruction of the shapes of lobes which developed at various times during the Late Wisconsin (Weichselian) retreat of the Laurentide ice sheet from the Great Lakes area according to Prest (1970). Ages (where available) of isochronous ice margins are given in thousands of years B.P. 
Reconstructions of the Late Weichselian ice lobe which flowed into the southern Baltic, show that although it occupied the Baltic basin, it was not confined between the rising flanks of the basin. The reconstruction of Nilsson (1968) shows it overlapping these flanks and Mörner and others' (1975) reconstruction show it to be almost entirely within the Baltic basin, though by no means restricted to its deepest part.

Reconstructions of the Late Devensian glacier lobe which flowed down the east coast of England show that it was not limited by a topographic basin; it flowed over an irregular surface of low relief. This lobe also coincides with a zone of soft sediments which overlies relatively impermeable chalk, compared with an area to the east which is underlain by thick, permeable'Tertiary beds.

The complex of lobes along the southern margin of the Late Wisconsin Laurentide ice sheet occurred in an area where glacial ponding produced much enlarged ancestors of the present Great Lakes and thus laid down thick sequences of lake muds. The complex of lobate re-advances in this area during the retreat of the Laurentide ice sheet might reflect substratum control of the type suggested here. Wright (1973) has argued that many of these lobes may have been produced by surges resulting from subglacial water damming because the glacier freezes to its substratum in the marginal zones. However, a surge that was not related to the geology of the glacier substratum would have spread in a fan shape rather than along a distinct axis, unless lateral movement was restricted by valley walls. However, there are many areas of very low relief $(<200 \mathrm{~m})$ in which the extreme lobate form is maintained and in which it is difficult to imagine that gently-sloping valley sides could have provided an effective barrier to lateral spreading.

\section{Evidence of Pleistocene ice-sheet profiles}

Mathews (1974) has used geological evidence to reconstruct the maximum surface elevations at several points on the south-west part of the Laurentide ice sheet and he concludes that the mean surface slope may have been as little as one-sixth as steep as typical modern profiles from Greenland and Antarctica, and for as much as $500 \mathrm{~km}$ from the ice-sheet margin. One possible explanation of these data is that a major surge of the south-west margin of the Laurentide ice sheet occurred, extending this margin far beyond the position it would have held before the surge. However, there is extensive evidence in the area investigated by Mathews, as there is at other points along the southern margin of the Laurentide ice sheet, that, rather than the surge being followed by rapid stagnation, the glacier remained active and re-advanced several times in a shorter period of time than would be expected if the glacier had to build up and surge again before a re-advance.

The processes which have hitherto been invoked to explain low profiles have been surge mechanisms, in which attainment of some threshold produces instability, usually de-coupling of the glacier from its bed by build up of a water layer. A rapid surge is released, followed by glacier stagnation and subsequent build-up, until another surge is produced. For the southwest margin of the Laurentide ice sheet we seem to need a mechanism which will allow the ice sheet to have a low profile, but to retain its activity. The substratum-controlled ice-sheet model presented here allows this to happen. A low-profile ice sheet of this type could be in a steady state, although one which could be easily disturbed, to produce surge-type instability. This could happen because of increases in the rate or pattern of accumulation (cf. Fig. 3) or changes in the position of the ice front which change the net hydrogeological characteristics of the glacier bed (Fig. 5). In addition, a thin ice sheet would be much more responsive to changing mass balance.

As the fluctuation of the glacier margin is not merely a function of mass balance, but also of the change in hydrogeologic and strength properties of those bed sediments along a flow line, different lobes attached to the same ice sheet might show a very different response to climatic 
change. It is interesting therefore to find that Wright ([1976]) records a "lack of clear time correlation between the advances of the Superior and the Green Bay-Lake Michigan lobes" at the southern margin of the Laurentide ice sheet.

\section{Rates of retreat}

Andrews (1973) drew attention to the rapid rate of average frontal retreat for the northwest, south-west, and southern sectors of the Laurentide ice sheet (between $80 \mathrm{~m}$ year-1 and $\left.3^{60} \mathrm{~m} \mathrm{year}^{-1}\right)$. If a surface profile based on modern analogues is assumed for these ice sheets, then about $280-1500 \mathrm{~kJ} \mathrm{~cm}^{-2}$ year $^{-1}$ is required to melt sufficient ice to cause the observed retreat. Estimates of the amounts of energy available in the atmosphere at this time suggest that this is up to 17 times too small to account for the inferred ice wastage. If these areas were occupied by low-slope ice sheets, a substantially smaller energy input would have been required to produce the observed retreat.

\section{Isostatic evidence}

Geological evidence from the northern North Sea basin (Jansen, 1976) indicates clearly that this area was a zone of confluence between the Scandinavian and British ice sheets during the Late Weichselian. However, reconstructed isobases for south-western Norway (Andersøn, 1960) and eastern Britain (Synge, 1977) appear to follow the respective coastlines and do not reflect the presence of a large ice mass in the North Sea. Thus, we have geological evidence for a widespread ice mass, but no evidence for a heavy load on the Earth's crust. To a certain extent this is true for much of the southern margin of the European ice sheet, for there is clear evidence for strong crustal subsidence beneath its rocky, mountainous northern fringes but little or no evidence that there was more than a slight subsidence beneath the soft sedimentcovered southern fringes. As is clear from the work of Brotchie and Sylvester (1969) and Peltier and Andrews (1976) this is unlikely to reflect merely rapid glacial advance and retreat over the southern areas without adequate time for crustal response. It could however reflect a change in the character of the ice sheet: A thick ice mass over the hard rocks of the northern areas which could sustain a thick ice sheet, but deformation of the soft sediment cover in the area to the south leading to the development of a thin, fast-moving plate of ice, similar in many respects to a floating ice shelf.

\section{Changes of ICE-SheEt Behaviour BetWeen GLAGIAL AND INTERGLAGial PERIOdS}

We have suggested that the deforming-bed model is capable of explaining several hitherto puzzling features of the southern margins of large Pleistocene ice sheets in areas which are currently temperate. However, the deforming-bed model has a considerable drawback, it is difficult to apply it to modern glaciers on anything but a local scale. Thus, it seems that the theory suffers from the uncomfortable implication that large Pleistocene ice sheets behaved differently from modern ones. We suggest however, that this conclusion is not so implausible as it seems, and that there are good reasons for believing that the behaviour of ice sheets in low latitudes during glacial periods could have been different from those in high latitudes during interglacial periods.

Reconstructions of glacier fluctuations during the Quaternary suggest that three major levels of glacierization occur in the northern part of the Northern Hemisphere (Fig. 7). The first level, typical of interglacial periods, has glaciers confined to an inner or core zone of glacierization, which are highland areas in currently temperate latitudes, and ice caps at or near sea-level in those parts of the Arctic where precipitation is sufficient to maintain them. In the second level of glacierization, assumed to be typical of interstadials during glacial periods, we assume that the ice caps extend to cover an intermediate zone over mountainous areas of 


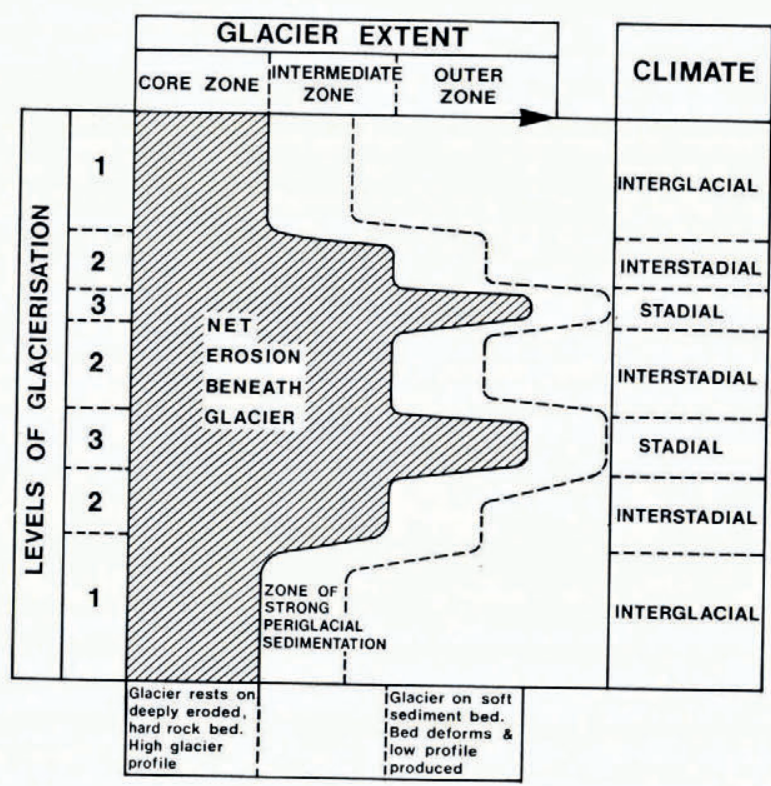

Fig. 7. Schematic diagram showing the extent of glaciers (shaded) during different climatic phases in passing from one interglacial to the next. Different levels of glacierization are appropriate to different climatic phases. Net erosion occurs beneath when the glacier is confined to a core zone, it is most likely beyond it. During glacierization level $I$, in an interglacial, profile. At glacierization level 3 , during stadial periods, it to rest on old, hard, deeply eroded rocks and thus to have a high to occur and to produce an unstable low profile in this area.

northern Europe, and over the Laurentide Shield in North America. The third level of glacierization, typical of the coldest (stadial) parts of glacial periods, has large ice sheets

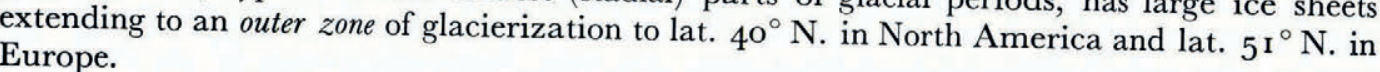

Using this simple model, the inner zone can be regarded as a core area, permanently occupied by ice during the Quaternary (glacierization levels $\mathrm{I}-3$ ). More extensive areas (intermediate zones) are occupied by ice during glacial periods but not interglacials (glacierization levels 2-3), these form the source areas from which expansion occurs to the outer limits of glaciation during the coldest stadial parts of glacial periods when level 3 is attained and all three zones are occupied. Thus, the time periods of glacier occupancy decrease from $100 \%$ in the inner zones occupied at level $\mathrm{I}$ to a relatively small time period in the outer zones, only occupied during level 3 (Fig. 7).

Glaciers inevitably produce net erosion of the bed on which they lie. The major part of the products of this erosion are deposited in a zone of net deposition around the glacier margin. Shallow shelf seas and freshwater lakes are particularly efficient traps for this sediment. Areas occupied by glaciers at the present day, equivalent to zone I in Figure 7 , are likely to have been areas of net erosion for much of the Quaternary. They are therefore unlikely to have substantial thicknesses of soft sediment beneath them, except at the perimeter, but they are likely to be underlain by relatively undeformable bedrock. This supports the observations of glaciers with a high-angle profile, determined by the rheology of ice alone.

The intermediate zones will tend to be zones of net deposition of sediment produced by glaciers in the inner (core) zone during interglacials, but they are likely to suffer net erosion during glacial periods when they will be occupied by expanding glaciers as glacierization 
The zone in which glaciers are most likely to be underlain by deformable sediment is the outer zone which will probably experience a relatively long period of sedimentation, but only a limited period of net erosion when ice is at its most extensive, occupying the outer zone during glacierization level 3. Thus, the outer zone is the zone in which we would most expect a glacier to be underlain by deformable sediments or relatively young and easily deformed rocks. Because of this we would suggest that the profiles and dynamics of large Pleistocene ice sheets in Europe and North America may have been strongly influenced, in their outer parts at least, by beds of deformable sediments, unlike modern ice sheets and glaciers which are less likely to have been influenced in this way.

The above scheme is of course highly idealized. Glacier-derived sediments are most likely to be deposited in low-lying areas or basins near to the ice margins and not on relatively high areas. In Europe, such areas of sedimentation were the continental shelves, the Baltic basin, and the low-lying European plain to the south of the Baltic. In North America they were the continental shelves, Hudsons Bay, and the areas of concentric lakes around the Laurentide Shield (White, 1972), in particular the Great Lakes area. These are precisely the areas in which, we suggest, there is evidence of the existence of low-profile ice masses during the last glaciation.

\section{Summary}

I. Existing theories of glacier movement assume that the ice moves over a rigid substratum.

2. Geological observations show that many ancient glacier beds are composed of soft deformable sediment; in some places this is also true of modern glaciers.

3. Measurements beneath a modern temperate glacier lying on till show that $90 \%$ of the basal movement of the glacier can be contributed by deformation within the till substratum rather than by internal flow or sliding at the ice-bed interface.

4. It is shown that if high water pressures develop in subglacial sediments, a threshold may be reached whereby subglacial sediments deform and lower the profile of the glacier. A theory is developed in which the glacier profile is related to the hydraulic and strength properties of underlying sediments. If these beds have a low hydraulic transmissibility the glacier may find a steady state as a thin sheet moving over continuously deforming sediments, analogous in some ways to an ice shelf.

5. There are several lines of evidence to suggest that such low profile substratumcontrolled glaciers may have been important during the Pleistocene:

(i) Anomalously low values of post-glacial isostatic rebound.

(ii) Margins which are extremely difficult to explain using surface profiles typical of most modern glaciers.

(iii) Very high retreat-rates which are difficult to explain by invoking typical modern profiles.

6. We suggest that bed instability resulting in low glacier surface profiles may have been an important feature of the margins of the Pleistocene ice sheets of North America and Europe, whereas this does not seem to be important in present-day glaciers except as an additional surge mechanism. Glaciers inevitably produce net erosion of their beds, and longterm glacial occupancy is likely to remove most unlithified sediments, to bite deeply into softer surficial rocks, and to expose hard crystalline basement. Modern glaciers are probably near to their most reduced Quaternary state and therefore tend to lie on well-eroded and relatively undeformable beds. Glaciers near to their Quaternary stadial maxima will probably have overlain both soft sediments deposited beyond glacier margins during the Quaternary, and also soft Tertiary and Mesozoic cover which has undergone little glacial stripping. Thus, the beds beneath the margins of Quaternary glaciers during their most extended phases are likely to have been relatively deformable, thus leading to low-angle surface profiles in the glaciers themselves. 


\section{REFERENCES}

Andersen, B. G. 196o. Sorlandet: i sen- og postglacial tid. Norges Geologiske Undersokelse, Nr. 2 10. Andrews, J. T. 1973. The Wisconsin Laurentide ice sheet: dispersal centers, problems of rates of retreat, and
climatic implications. Arctic and Alpine Research, Vol. 5, No. 3, Pt. 1, p. 185-99.

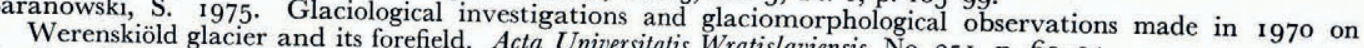

Boulton, G. S. [ ${ }^{\mathrm{C}} \mathrm{I}$ 975.] Processes and patta Universitatis Wratislaviensis, No. 251, p. 69-94.

A. E., and Moseley, F., ed. Ice ages: ancient and modern. Liverpool, Seel House Press, approach. (In Wright,

Boulton, G. S., and Paul, M. A. 1976. The influence of Liverpool, Seel House Press, p. 7-42.)

glacial tills. Quarterly fournal of Engineering Geology, Vol. 9 , No. processes on some geotechnical properties of

Boulton, G. S., and thers.

south-east Iceland, by G. S. Boulton, D. L p. $135-45$.

Brotchie, J. F., and Sylvester, R. 1969. On crustal flexure. Fournal of Geophysical Research, Vol. p. $5240-52$.

Holdsworth, G. H. 1977. Surge activity on the Barnes Ice Cap. Nature, Vol. 269, No. 13, p. 588-90.
Jansen, J. H. F. 1976. Late Pleistocene and Holocene history of the northern North Sea, based on a reflection records. Netherlands fournal of Sea Researche history of the northern North Sea, based on acoustic Jones, A. S. 1978. The dependence of of Sea Research, Vol. Io, No. I, p. 1-43. and surface temperature. Fournal of Glaciology, Vol. 20 , No, in ice sheets on longitudinal variations in velocity

Kazi, A., and Knill, J. L. Iournal of Glaciology, Vol. 20, No. 82, p. 31-39. Happisburgh and Cromer, Nortill between

Kupsch, W. O. 1962 . Ice-thrust ridges in werty Journal of Engineering Geology, Vol. 2, No. 1, p. $63-86$.

Kupsch, W. O. I962. Ice-thrust ridges in western Canada. Fournal of Geology, Vol. 7o, No. 5, p. 582-94. Bd. I 7, Ht. 8, p. I-14. Løken, O. H. I969. Evidence of surges on the Barnes Ice Cap, Baffin Island. Canadian Fournal of Earth Sciences,
Vol. 6, No. 4, Pt. 2, p. 899-90 I. Mathews, W. H. I 974 . Surface profiles of the Laurentide ice sheet in its marginal areas. Fournal of Glaciology,
Vol. 13, No. 67 , p. 37-43.

Mörner, N.-A., and others. 1975. Late Weichselian deglaciation of the Baltic, by N.-A. Mörner, T. Floden, H. Haxner, and A. Elhammer. Baltica, Vol. 6, p. 55-69.

Nilsstn, E. 1968. Södra Sveriges senkvartära historia; geokronologi, issjöar, och landhöjning. Kungliga Vetenskapsakademiens Handlingar, Fjäde Ser., Bd. 12, Nr. 1 .

Nye, J. F. 1957. The distribution of stress and velocity in glaciers and ice-sheets. Proceedings of the Royal Society of London, Ser. A, Vol. 239, No. 1216 , p. $113-33$.

Peltier, W. R., and Andrews, J. T. 1976. Glacial isostatic adjustment. I. The forward problem. Geophysical rest, V. K. I R7oyal Astronomical Society, Vol. 46, No. 3, p. 605-46.

edition], p. 675-764.
[fifth

Schytt, V. I 969 . Some com No. 4, Pt. 2, p. $867-73$. Vol. 37, Pt. 4, p. 392-40o. Synge, F. M. I 977 . Records of sea levels during the late Devensian. Philosophical Transactions of the Royal Society
of London, Ser. B, Vol. 280, No. 972, p. 2 I I-28.

Weertman, J. 196r. Equilibrium profile of ice caps. Fournal of Glaciology, Vol. 3, No. 3o, p. 953-64.

White, W. A. 1972. Deep erosion by continental ice sheets. Geological Society of America. Bulletin, Vol. 83, No. 4,

Amerika im Eiszeitalter.

Wright, H. E., jr. I 973 . Tunnel valleys, glacial surges, and subglacial hydrology of the Superior lobe, Minnesota. Geological Society of America. Memoir i 36, p. $25 \mathrm{I}-76$.

Wright, H. E., jr. [1976.] Ice retreat and revegetation in the western Great Lakes area. (In Mahaney, W. C., ed. Quaternary stratigraphy of North America. Stroudsberg, Pennsylvania, Dowden, Hutchinson, and Ross Inc.,
p. II $19-32$.)

\section{DISGUSSION}

S. R. Moran: Our observations from North Dakota, Alberta, and the prairies in general, suggest that this type of model makes considerable sense. (a) The glacial thrust features and "unique" streamlined forms that we observe in the prairies appear to be restricted to the prairies. Therefore, we tentatively suggest that something is in fact different in the prairies compared with other areas with "normal" ice caps (Lee Clayton is the main source of this idea). (b) In a study of Lake Agassiz and ${ }^{14} \mathrm{C}$ dates in Des Moines-James lobes several years 
ago we came to the conclusion that retreat rates of 2.5 to $3.5 \mathrm{~km} /$ year were likely in this area. Thus our observations from the prairies of North America tend to support your ideas.

D. E. Sugden: While finding your ideas attractive, I wonder whether the geological evidence you used in support can be explained another way. Could the asymmetry of the Fennoscandian ice sheet simply reflect the high mountain rim of Scandinavia, thus providing an analogy with the asymmetric ice sheet of southern Greenland today? Also could the low gradients of the Laurentide ice sheet in the western plains simply reflect the high altitude of that margin, i.e. the lower altitude steeper gradients are just not represented?

G. S. Boulton: First, we have not been able to reproduce the extreme asymmetry of the Scandinavian ice sheet either from modern analogues or from theoretical reconstructions assuming extreme accumulation and temperature contrasts between the north-west and southern flanks. Secondly, areas in which geological evidence requires retreat rates of 2.5 to $3.5 \mathrm{~km} /$ year (as Moran has just reminded us) include the Western Great Lakes area between 500-1 $000 \mathrm{~m}$ in altitude. A conventional parabolic profile would still have a near-snout gradient of about $\mathrm{I} / \mathrm{I}$ oo and require excessively large net ablation-rates of $30 \mathrm{~m} / \mathrm{year}$ to produce the inferred retreat-rates.

A. Dreimanis: In support of your model of a low-profile zone of the ice sheets in the areas of deformable soft sediments, I may add that the number of lobes moving along lowlands and topographic depressions was considerably higher than shown on your maps of the Laurentide and Scandinavian ice sheets over the soft sediment areas. However, there is also good evidence for local centres of glacial outflow in the periphery of the Laurentide ice sheet, and their existence here and there would not contradict the general low-profile situation; on the contrary, both may be combined. As concerns the permeability differences between the bedrock and sediment substrata, large areas of clayey "soft" sediments may have been less permeable than fractured bedrock, and high pore water.pressure in them might have governed their behaviour under the ice and their influence upon the glacial flow.

Boulton: The second part of Professor Dreimanis's comment is precisely what is envisaged in our model.

I. M. Whillans: According to the model, all the water produced by interior basal melting percolates through the sediments near the margin. How would the results be affected if most of this water left the glacier through channels and did not percolate through the sediments?

Boulton: Even if most of the water did leave the glacier via channels, it would still find its way into the channels by intergranular flow through the subglacial sediments. The effect would be to help drain the sediments and thus lower water pressures. Some insight into the magnitude of this effect can be gained from the frequency of eskers in formerly glaciated terrains. Tentative results suggest that water pressures will be substantially lowered in coarse sediments and low profiles are difficult to produce, but in fine-grained sediments substantial lowering of the profile still occurs. 